the others, and it is belicved five piles are amply sufficient to resist any mass of ice that can come between the wharf and the pier.

It is not considered necessary to revise the estimates heretofore made, as the modifications proposed extend only to details involving no additional expense. I have the honor to be

$$
\begin{aligned}
& \text { Youx most obt. servt., } \\
& \text { (Signed) W. H. Enonx, } \\
& \text { 1st Lient. Top. Eng. }
\end{aligned}
$$

Topographical Bureau, Nay 20, 1844.

Explanations of Plate I. -Fig. 1, elevation of the picr; fig. 2, plan of braces and collars; fig. 3 , top view of centre collars for braces; fig. 4 , side view of centre collars for braces; fig. 5, top view of ontside collars for braces; fig. 6 , side view of outside collars for braces; fig. 7 , mooring shackle enlarged; fig. 8 , collar for mooring shackle; lig. 9 , pile head; fig. 10, nut for pile hoad.

$a$, mooring shackle; $b$, collar for mooring shackle; $c$, covering plate; $d$, braces; ; outside view; $f$, inside view; $g$, Mitchell's screv.

The following detailed description of Mitchell's mooring screw, and its application to the construction of the Wyre light-house, was prepared for publication before our receipt of the foregroing article, and mey be considered as an appropriate appendix to it: Conr. Pur.

Hescription of Mr. Mitchell's Patent Screw Mooring, as being now luid down in the Port of London. By J. Erines, Esq., Surveyor.

'This sort of mooring is constructed, as its name implies, on the principle of the screw, but differing essentially in form from that well known instrument; for while the spiral thread makes little more than one turu round its shaft, it is, at the same time, extended to a very broad flanch, the hold which it takes of the ground being proportional with its breadth of disk.

Where it is nccessary to provide against a very heavy strain, Mr. Mitchell has moorings of 3 fect 6 inches diameter, and the principle is capable of still further extension.

A mooring of the above diameter presents a resisting surface equal to about ten square feet; whereas the palm of the largest anchor in the British navy does not exceed half that size; and some estimate of its holding powers may be formed, when it is shown that this broad surface can be screwed to a depth many times greater than that to which the palm of an anchor can cver descend.

The cuethod of laying down the mooring is briefly thus:-A strong morig chin ining so attached to it as to allow the screw to ture fret: withont corrying the chain round with it, a powerful iron shaf is tive frec firnly in the upper part of the mooring, which is formec squart for that purose, sctting in the same manner as a key to harp, or piano forte, in winding up; it is then lowered by the moorin: chain, joint after joint being added to the shaft till the mooring ha reached the ground; light levers of 12 feet in length are then appliet to the shaft in the manner of a capstan, when the operation of screw ing the mooring into the ground commences. 
Two boats, or barges, having beeu moored firmly, head and stern, close alongside cach other, and the upright shaft rising between them about midships, the men place themselves at the bars, and move round from one boat to the other, the two giving them a safe aud convenicut plition; by a simple contrivance the levers a re occasionally shipred upwards, as the screw and shaft sink into the ground.

When the number of men employed can no louger force the screw rouml, the levers are removed, and the shaft drawn out of the ground, leving the mooring firmly jombedded with the chain attached to it: a buoy being shackled to the other end of the chain the work is comyloted, the lime reguined for the whole operation seldom exceeding a diw hours.

Fig. 11, Plite 1, shows the screw mooring, as prepared for use. $u$, is a sjiral, or screw, flanch of about one tum and a half, having at hollow cylindrical centre, as shown in fig. 12, and of cast-iron in one picce; $b$, is a wrought-iron spindle, which passes through the cylindri. eal socket of the serew flanch, somewhat tapering in form, as shown in lig. 13 , and when driven up tight, is fixed thereto by a forelock, which bisses through both; it is formed with a square head, $c$, to recoive the key for screwing it into the ground; $d$, is a collar of wrought-iron, the front of which is shown in fig. 14, fitted so "s to tarth frecly on the upper part of the shaft of the spindic below the collar. Fig. 12 , shows the upper surface of the spiral tlanch; fig. 1 , the spin(3) ; and fig. 14, the collar and shackle. The shackle is fixed to the spindle by means of the loose collar, in order to prevent the dragging romnd, and the consequent fouling of the chain, whilst the spindle is being turned in, or ont, of the ground.

Civ. Tng. \& Arch. Journ.

\section{Description and Structure of the Wyre (Seaward) Lighthouse,} leading to Port Fleelwood. By Com. H. M. Den has, R.N., F.R.S.

It was my study, when planning this navigation, to identify the remotest spit of bank turning into it, without subjecting the mariner to the treacherous, and, at best, but partially lighting agent, a $L i g h t$ Fessel; Messrs. Alexander Michell \& Son, of Belfast, readily tuok up the proposition, and the Board of Directors of the railway and harbor project, as readily adopted the application of Mitchell's ingenious mooring screw to the insertion and basing of piles, or pillars, in sub-marine foundation. I had given much trouble to Messrs. Mitchcil, when mavailingly submitting their plans and spccifications to the Liverpool Dock Company, (Oct. 4, 1835,) of so perfect a mode of establishing lights out upon the very banks of a ravigation, wheroby the power and object of a light-house is enhanced by proximity with the anxious observer from sea. In fact, a light-house can be thus erected upon any under-water spit, as indifferent to a 30 feet rise of tide and channel surge, whilst sending forth its light of the same character and stability, as if on the main land; thereby throwing it more intensely and effectively on the region required, especially where 